\section{A TRIBUTE}

Long-time Society member Mary Houston passed away in July 2019. A lifelong educator and avid naturalist, Mary touched the lives of countless people.

A University of Saskatchewan graduate, Mary began her professional life teaching at Yorkton Collegiate Institute. With her marriage to Stuart Houston in 1951 she embarked on a very busy life, raising four children and assuming a variety of volunteer responsibilities, as well as working with Stuart on an energetic array of bird-banding projects, research and publications.

Mary was a bird-bander for 63 years, personally banding pelicans, cormorants, and gulls, then later shifting to backyard species. She banded many songbirds, including 6,000 Dark-eyed Juncos, 3,500 White-throated Sparrows and 3,200 redpolls. In winter months, Mary banded a record 5,387 Bohemian Waxwings, more than the total of all other North American bird banders combined. ${ }^{1}$ She also provided Stuart's owl, hawk and vulture-banding crews with an always dependable and much appreciated supply of water, iced tea, sandwiches (notably peanut butter and raisin) and cookies.

Mary introduced many school classes and individual students to birding. She often invited school classes to her home, or led them on outings at Pike Lake. In 1968, Mary and Stuart became the first adult advisors for a brand-new Saskatoon Junior Natural History Society. Mary proceeded to organize a trail of nest boxes for bluebirds over 200 miles long - a project inspired by successes with similar projects in the Brandon and Indian Head areas designed to "bring back the bluebirds". The junior naturalists built 270 nest boxes for their section
TO MARY

of the trail, and assisted with the checking and banding that had to be done every 10 days or so between May and July (it took four full days to do the whole route). Mary led this activity every year until 2005 when she finally handed it off to a team (Greg Fenty, Melanie Elliott, Jan Shadick and Tim Haughian) to take her place. During her tenure, she banded over 8,000 bluebirds and over 18,000 Tree Swallows.

Long time Saskatoon society members will remember with fondness many post-Boxing Day Bird Count socials that Mary hosted. She also devoted a phenomenal number of hours for over 30 years (with the exception of two years when she wasn't in the province) to compiling all of the Christmas Bird Count data from across the province into one annual report.

In her lifetime, Mary served on the Saskatchewan Provincial Council of Girl Guides of Canada, and on the executive of the Canadian Nature Federation, the Saskatchewan Natural History Society, the Saskatoon Nature Society, the University Women's Club and the Anglican Church Women at her church. She has authored and coauthored many journal articles, one book, and several book chapters, and provided an unimaginable amount of critical review and proof-reading, including, most recently, for Birds of Saskatchewan.

The Saskatoon Council of Women, inducting Mary into the Saskatoon Women's Hall of Fame in 2011, called her "one of the city's most remarkable women". She was one of the first four recipients of a Fellows Award from the Saskatchewan Natural History Society in 1987 (Stuart was another of the four). Other awards Mary received over

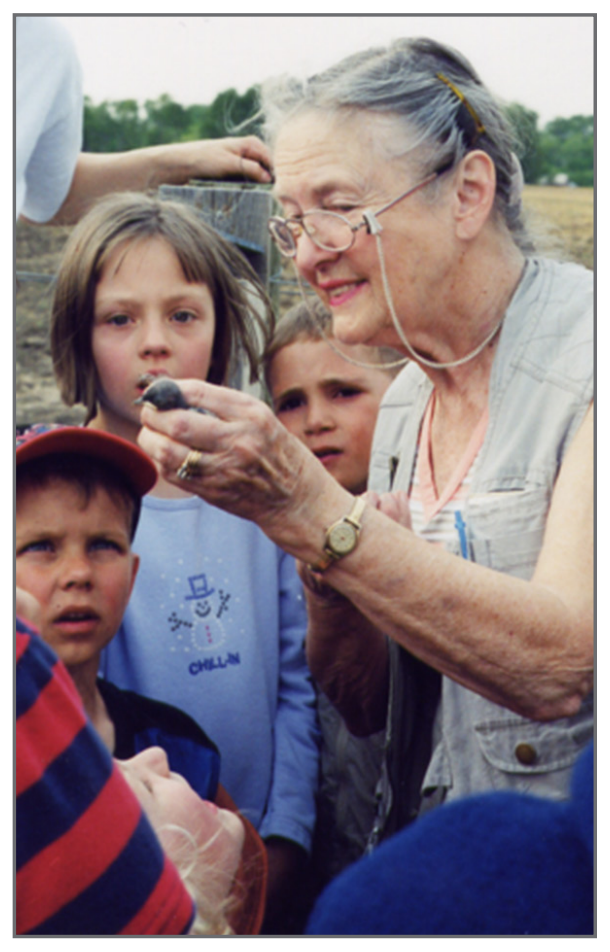

Photo credit: Greg Fenty.

the years include Meewasin's Conservation Award in 1996, the Douglas Pimlott Conservation Award from the Canadian Nature Federation in 1988, Nature Saskatchewan's Conservation Award in 2003, and the Saskatchewan Volunteer Medal and the Saskatchewan Centennial Medal in 2006. She was added to the $U$. of $S$. College of Education Alumni Wall of Honour in 2010, and was named an Alumna of Influence by the College of Arts and Science in 2013.

Mary is both mourned and celebrated by all who knew her, and most keenly by her husband Stuart, their four children, nine grandchildren, and one greatgrandchild.

Reprinted from the September 2019 Saskatoon Nature Society newsletter, with permission.

1. Houston CS (2016) Mary Houston: North America's Pre-eminent Bohemian Waxwing Bander. Blue Jay 74(4):25-27. 